Check for updates

The BMJ

Cite this as: BMJ 2021;373:n1677 http://dx.doi.org/10.1136/bmi.n1677 Published: 30 June 2021

\section{Covid-19: Government must tackle stark regional health inequalities exposed by pandemic, says Marmot}

\author{
Elisabeth Mahase
}

Greater Manchester had a 25\% higher covid-19 death rate during the pandemic than England as a whole, a sign of how the pandemic has worsened existing inequalities, a report from Michael Marmot has found. ${ }^{1}$

As a result of the pandemic, life expectancy throughout England has fallen, but it has declined most steeply in the north west-falling by 1.6 years in men and 1.2 years in women in 2020 , compared with 1.3 years (men) and 0.9 years (women) in the country overall.

The striking findings were revealed as part of a review carried out by Marmot, who is known for his decades of work on health inequalities, including the 2010 "Marmot review."

Build Back Fairer in Greater Manchester, ${ }^{1}$ a new report commissioned by the Greater Manchester Health and Social Care Partnership and published on 30 June, links itself to Boris Johnson's "build back better" slogan and outlines recommendations for improving the situation in Greater Manchester that can also be applied to the rest of the country.

Key recommendations include:

- Doubling Greater Manchester's budget for prevention within five years and developing a systemwide prevention and health spending target for the whole region by the end of 2021

- Increasing funding and support for training and apprenticeships in deprived communities

- Identifying the minimum income for healthy living in Greater Manchester and advocating for national resources to provide this in the public sector and help businesses to pay it

- Investing in routine data collection to enable monitoring of reductions in inequalities of wellbeing, opportunities, and community cohesion

- Promoting increased local control of employment services, the labour market, social housing, and early years policies and services; and

- Advocating for a greater share of resources for regions and local authorities hit particularly hard by covid-19.

The report emphasises that now is an opportune time to take these actions, as the pandemic has put health and equity at the "forefront of the national consciousness," while the public and political appetite to remedy the "unfairness of economic and social arrangements, ethnic disadvantage and racism and the extent of health inequalities" may have increased.

\section{Levelling up}

Greater Manchester's mayor, Andy Burnham, who launched The Marmot Review 10 Years On in 2020, ${ }^{3}$ said, "The pandemic has brutally exposed just how unequal England actually is. People have lived parallel lives over the last 18 months. People in low paid, insecure work have often had little choice in their level of exposure to covid-19 and the risk of getting it and bringing it back home to those they live with.

"Levelling up needs to start in the communities that have been hit hardest by the pandemic. To improve the nation's physical and mental health, we need to start by giving all of our fellow citizens a good job and good home. We are grateful to Michael Marmot for showing how Greater Manchester can improve the health of our residents, and we hope the government will back us with the resources and powers to put better health at the heart of our recovery."

Marmot, who is director of the UCL Institute of Health Equity, has said that if the government is truly serious about levelling up health inequities it must put equity of health and wellbeing at the heart of its strategies rather than narrow economic goals.

Writing in The BMJ, ${ }^{4}$ Marmot and the report's coauthor Jessica Allen said, "Build Back Fairer in Greater Manchester can be seen not only as a contribution to improving health and health equity in Greater Manchester, but a demonstration to national government as to what they need to do, if serious about levelling up.

"If levelling up includes greater health equity, there is an urgent need to build a society based on principles of social justice, narrower inequalities in wealth and income, prioritising equity of health and wellbeing, while responding to the climate crisis."

\footnotetext{
Marmot M, Allen J, Boyce T, Goldblatt P, Morrison J; Institute of Health Equity. Build back fairer in Greater Manchester: health equity and dignified lives. Jun 2021. https://www.instituteofhealthequity.org/resources-reports/build-back-fairer-in-greater-manchester-health-equity-and-dignifiedlives.

2 Marmot M, Allen J, Goldblatt P, et al. Fair society, healthy lives (the Marmot Review). Feb 2010. https://www.instituteofhealthequity.org/resources-reports/fair-society-healthy-lives-the-marmot-review.

3 Marmot M. Health equity in England: the Marmot review 10 years on. BMJ 2020;368:m693. doi: 10.1136/bmj.m693 pmid: 32094110

4 Marmot M, Allen J. Michael Marmot and Jessica Allen: Building back fairer in Greater Manchester. BMJ Opinion 2021 Jun 30. https://blogs.bmj.com/bmi/2021/06/30/michael-marmot-and-jessica-allenbuilding-back-fairer-in-greater-manchester/.
}

This article is made freely available for use in accordance with BMJ's website terms and conditions for the duration of the covid-19 pandemic or until otherwise determined by BMJ. You may use, download and print the article for any lawful, non-commercial purpose (including text and data mining) provided that all copyright notices and trade marks are retained. 